\title{
Factors Influencing Anxiety Among WeChat Users During the Early Stages of the COVID-19 Pandemic in Mainland China: Cross-sectional Survey Study
}

Changqing Zou ${ }^{1 *}$, MS; Weiyu Zhang ${ }^{2 *}$, BM; Kristin Sznajder ${ }^{3}$, PhD; Fengzhi Yang², BM; Yajing Jia ${ }^{2}$, BA; Ruqing $\mathrm{Ma}^{2}, \mathrm{BA}$; Can Cui ${ }^{2}$, BA; Xiaoshi Yang ${ }^{2}, \mathrm{PhD}$

\footnotetext{
${ }^{1}$ Department of Humanities and Social Sciences, China Medical University, Shenyang, China

${ }^{2}$ Department of Social Medicine, School of Public Health, China Medical University, Shenyang, China

${ }^{3}$ Department of Public Health, College of Medicine, Pennsylvania State University, Philadelphia, PA, United States

*these authors contributed equally
}

\section{Corresponding Author:}

Xiaoshi Yang, $\mathrm{PhD}$

Department of Social Medicine, School of Public Health

China Medical University

No 77 Puhe Road, Shenyang North New Area

Liaoning Province

Shenyang, 110122

China

Phone: 8618900910796

Email: xsyang@cmu.edu.cn

\section{Abstract}

Background: The rapid outbreak of COVID-19 around the world has adversely affected the mental health of the public. The prevalence of anxiety among the public has increased dramatically during the COVID-19 pandemic. However, there are few studies evaluating the effects of positive psychological responses and information-seeking behaviors on anxiety experienced among social media users during the COVID-19 pandemic.

Objective: This study evaluated the prevalence of anxiety and its associated factors among WeChat users in mainland China during the early stages of the COVID-19 pandemic.

Methods: From February 10 to February 24, 2020, a nationwide, web-based cross-sectional survey study was carried out using convenience sampling. Participants' levels of anxiety, positive psychological responses, and information-seeking behaviors were assessed. The survey was distributed among WeChat users via the WeChat smartphone platform. Chi-square tests and multivariable logistic regression analyses were performed to examine the factors associated with anxiety.

Results: This study found that the prevalence of anxiety (Generalized Anxiety Disorder 7-item [GAD-7] scale score $\geq 7$ ) among WeChat users in China was $17.96 \%$ (446/2483) during the early stages of the COVID-19 pandemic. Results of multivariable logistic regression analysis showed that information-seeking behaviors such as cannot stop searching for information on COVID-19, being concerned about the COVID-19 pandemic, and spending more than 1 hour per day consuming information about the pandemic were found to be associated with increased levels of anxiety. Additionally, participants who chose social media and commercial media as the primary sources to obtain information about the COVID-19 pandemic were found more likely to report anxiety. Conversely, participants who were confident or rational about the COVID-19 pandemic were less likely to report anxiety. Conclusions: This study found that positive psychological responses and information-seeking behaviors were closely associated with anxiety among WeChat users during the COVID-19 pandemic in China. It might be paramount to enhance mental well-being by helping people respond to the COVID-19 pandemic more rationally and positively in order to decrease symptoms of anxiety.

(J Med Internet Res 2021;23(5):e24412) doi: 10.2196/24412

\section{KEYWORDS}

anxiety; COVID-19; information seeking behavior; positive psychological response; health information; public health emergency; mental health; online survey; China; cross-sectional study 


\section{Introduction}

In January 2020, the World Health Organization classified COVID-19 as a public health emergency of international concern [1,2]. COVID-19 spread rapidly to 208 countries and regions and became a global pandemic, resulting in more than 30 million cases of infection and over 950,000 deaths worldwide, as of September 18, 2020 [3,4]. The sudden outbreak of COVID-19 adversely impacted the daily life and mental health of the public, which demanded urgent solutions [5-12].

The COVID-19 pandemic generated a psychological crisis among the public as the prevalence of mental disorders, including anxiety and depression, increased [13-18]. Various sources of information, including official media channels, social media, and the local government or community, could significantly affect the public's psychological responses to emergency events and their mental well-being. Recent research has found that excessive information-seeking behaviors have been closely related with mental disorders, including anxiety and depression, during the COVID-19 pandemic $[19,20]$. Individuals with anxiety tend to focus on negative information and correspondingly experience negative psychological responses [21]. The frequency and daily duration of social media use was higher in areas with a higher number of COVID-19 cases. High levels of social media consumption were associated with increased mental distress, especially among individuals with high levels of fear [22]. The metacognitive model illustrates that certain behaviors such as controlling behaviors, reassurance seeking, and checking behaviors are positively associated with anxiety [23-25]. Thus, excessive media consumption could lead to harmful psychological responses, which could increase anxiety among these individuals during the COVID-19 pandemic.

Positive psychological responses to the COVID-19 pandemic among the public play a crucial part in reducing anxiety. Positive thoughts and attitudes could help individuals cope with stressors [26]. A recent study found that hope can contribute to anxiety prevention [27]. The theory of rational emotive behavior therapy indicates that rational beliefs can alleviate symptoms of anxiety and other mental distress [28,29]. Additionally, cognitive behavioral models of health anxiety indicate that negative emotions and misinterpretations of health-related stimuli could increase the chances of developing anxiety [30-33]. Therefore, promoting positive psychological responses and initiating emotion regulation and positive perceptions of health-related information, such as keeping a positive attitude and being rational, are necessary for the public to be able to better cope with stress [34].

Researchers have studied the pathogenic and epidemiological characteristics, epidemiological trends, as well as the prevention and treatment of COVID-19 [35-43]. However, studies focused on the relationship between information-seeking behaviors and anxiety during the COVID-19 pandemic are sparse. Therefore, this study focused on the evaluation of the prevalence of anxiety and its association with positive psychological responses and information-seeking behaviors among users of WeChat- the most popular social media platform in Mainland China—during the COVID-19 pandemic.

\section{Methods}

\section{Study Participants and Procedure}

In order to examine the prevalence of anxiety among WeChat users during the COVID-19 pandemic, a cross-sectional study design using convenience sampling was employed via a web-based WeChat platform developed by the Department of Environmental Health of China Medical University in China. Due to the urgency of the COVID-19 pandemic and the necessity of timely acquisition, the questionnaire was first uploaded to this web-based WeChat platform. Next, the survey was distributed via all the open WeChat groups of the research assistants, to render the survey easily available to their close contacts. The survey was distributed between February 10 and February 24, 2020, during which we achieved a sample size that was adequate in accordance with previous related studies [44-47]. The questionnaire comprised the validated Chinese version of the Generalized Anxiety Disorder 7-item (GAD-7) scale, questions on positive psychological responses, and questions on information-seeking behaviors practiced during the early stage of the COVID-19 pandemic. The questionnaire took about 20 minutes to complete.

The inclusion criteria for participation in this study were as follows: at least 18 years of age, ability to read and write Chinese, ability to complete the web-based questionnaire by themselves using a smartphone, ability to offer electronic signed informed consent, and voluntary participation. The exclusion criteria were as follows: undergoing any therapy for psychological illness, history of any drug dependence, and diagnoses of any diseases or impairments that would prevent them from completing the questionnaire independently. The questionnaire had been preset for submission only after all the questions were answered within the range of the selected choices. Only data from complete questionnaires were analyzed.

\section{Ethics Statement}

This study was carried out in conformance with the Declaration of Helsinki (1989). The study protocols were approved by the Ethics Committee of China Medical University.

\section{Demographic Characteristics of WeChat Users}

The survey collected participants' demographic characteristics, including gender (male or female), age, marital status (married or other), occupation, education, and monthly income. Occupation was further classified into government worker, health care worker, professional staff (teacher, lawyer, journalist, etc), employee of enterprises, commercial personnel, soldier, student, and other. Education was further classified into junior college or below, bachelor's degree, and master's degree or above. Monthly income was categorized as follows: $\leq ¥ 5000$ ( $\leq$ US \$725.19), ¥5001-10,000 (US \$725.34-1450.39), and >¥10,000 (>US \$1450.39).

\section{Measurement of Anxiety}

The validated Chinese version of the GAD-7, one of the most reliable tools to measure generalized anxiety disorder, was used 
to assess anxiety among the study participants during the early stages of the COVID-19 pandemic [48]. Psychological problems related to anxiety were evaluated with a 4-point Likert-type scale, with options including "not at all sure=0", "several days $=1$ ", "over the half of the days=2" and "nearly every day $=3$," resulting in a total score ranging from 0 to 21 . The cutoff score for anxiety was set at $\geq 7$, based on the total GAD-7 score [49-51], with Cronbach $\alpha=.939$ for GAD-7. The results of the factor analysis indicated that the seven items of the positive psychological responses tested were extracted as one component, which contributed to $73.518 \%$ of the variance (Kaiser-Meyer-Olkin [KMO] $=0.935, P<.001]$. The indicators of reliability and validity were good.

\section{Measurement of Positive Psychological Responses}

Positive psychological responses included "being confident," "being hopeful," and "being rational" in the past 2 weeks. They were measured by "yes" or "no" questions (Cronbach $\alpha=.788$ ). The results of the factor analysis indicated that the three items of the positive psychological responses tested were extracted as one component, which contributed to $70.932 \%$ of the variance $(\mathrm{KMO}=.638, P<.001)$. The indicators of reliability and validity were good.

\section{Measurement of Information-Seeking Behaviors}

Information-seeking behaviors were assessed using three self-developed questions; these behaviors were assessed in the following four categories: (1) cannot stop searching for information about the COVID-19 pandemic, (2) being concerned about the COVID-19 pandemic, (3) time spent consuming information about the COVID-19 pandemic (ie, <1 h, 1-2 h, or $\geq 3 \mathrm{~h}$ ), and (4) sources of information about the COVID-19 pandemic (social media and commercial media, central and local official media, basic-level government media, and community media). Responses to the item "cannot stop searching for information about the COVID-19 pandemic" included "agree," "not sure," and "disagree." Whether participants were concerned about the COVID-19 pandemic and their sources of information about the pandemic were assessed by "yes" or "no" questions.

\section{Statistical Analyses}

SPSS software (version 23.0; IBM Corp) was used to perform all statistical analyses. Chi-square tests were applied to assess bivariate associations with anxiety and the variables of interest. Anxiety was assessed using the binary variable (anxiety or no anxiety, as measured by the GAD-7 scale). Multivariable logistic regression analysis showed that the factors associated with anxiety were assessed while controlling for confounding variables. The variables included in the multivariable logistic regression analysis included age as a continuous variable and other variables as categorized variables. The responses were not included in the analysis when more than $95 \%$ of individuals had the same response to the categorical independent variables. Findings were considered statistically significant when a two-tailed $P$ value was <.05.

\section{Results}

\section{Demographic Characteristics and Prevalence of Anxiety Among WeChat Users}

In this study, we observed that 446 of 2483 (17.96\%) Chinese WeChat users who participated in our survey experienced anxiety. A total of 2501 adults participated in this survey and 2483 of them provided complete and logical answers, resulting in a valid response rate of $99.28 \%$. The demographic characteristics of the participants and results from the bivariate analysis of anxiety are presented in Table 1 . The mean age of participants was 34 (SD 12.82) years. Of the 2483 participants, $1550(62.42 \%)$ were female, and $278(17.94 \%)$ of them reported having experienced anxiety. About half of the participants $(1239 / 2483,49.90 \%)$ were married. Their occupations were classified into three groups according to their distribution and frequency: (1) government worker, health care worker, teacher, lawyer, or journalist (515/2483, 20.74\%); (2) student (954/2483, $38.42 \%$ ); and (3) other, including employee of enterprises, commercial personnel, or soldier (1014/2483, 40.84\%). More than half of the participants had a bachelor's degree (1394/2483, $56.14 \%)$, and many had a master's degree or above (800/2483, $32.22 \%)$. The remaining $11.64 \%$ (289/2483) participants whose educational level was "some college or below" showed significantly higher prevalence of anxiety $(61 / 289,21.11 \%)$ than the other two groups. With regard to the distribution of monthly income, $40.03 \%$ (994/2483) of the participants earned $\leq ¥ 5000 \quad$ ( $\leq$ US $\$ \$ 725.19), \quad 35.60 \% \quad(884 / 2483)$ earned $¥ 5001-10,000$ (US \$725.34-1450.39), and 24.37\% (605/2483) earned $>¥ 10,000$ ( $>$ US \$1450.39). 
Table 1. Prevalence of anxiety and associated factors among study participants ( $\mathrm{N}=2483)$.

\begin{tabular}{|c|c|c|c|c|c|}
\hline Variable & Participants, n (\%) & Anxiety experienced, n (\%) & No anxiety experienced, $\mathrm{n}(\%)$ & Chi-square $(d f)$ & $P$ value \\
\hline \multicolumn{6}{|l|}{ Demographic characteristics } \\
\hline Gender & & & & $0.004(1)$ & .96 \\
\hline Male & $933(37.60)$ & $167(17.90)$ & $766(82.10)$ & & \\
\hline Female & $1550(62.40)$ & $278(18.00)$ & $1272(82.00)$ & & \\
\hline Age (years) & & & & $1.985(1)$ & .17 \\
\hline$\leq 35$ & $1474(59.33)$ & $278(18.86)$ & $1196(81.14)$ & & \\
\hline$>35$ & $1009(40.67)$ & $168(16.65)$ & $841(83.35)$ & & \\
\hline Marital status & & & & $0.071(1)$ & .79 \\
\hline Married & $1239(49.90)$ & $220(17.76)$ & $1019(82.24)$ & & \\
\hline Other & $1244(50.10)$ & $226(18.17)$ & $1018(81.83)$ & & \\
\hline Occupation & & & & $4.042(2)$ & .13 \\
\hline $\begin{array}{l}\text { Government worker, health } \\
\text { care worker, teacher, lawyer, } \\
\text { journalist }\end{array}$ & $515(20.74)$ & $85(16.50)$ & $430(83.50)$ & & \\
\hline Student & $954(38.42)$ & $160(16.77)$ & $794(83.23)$ & & \\
\hline Other & $1014(40.84)$ & $201(19.82)$ & $813(80.18)$ & & \\
\hline Education & & & & $2.780(2)$ & .25 \\
\hline College and below & $289(11.64)$ & $61(21.11)$ & $228(78.89)$ & & \\
\hline Bachelor's degree & $1394(56.14)$ & $238(17.07)$ & $1156(82.93)$ & & \\
\hline Master's degree and above & $800(32.22)$ & $147(18.38)$ & $653(81.63)$ & & \\
\hline Monthly income (¥) & & & & $1.569(2)$ & .46 \\
\hline$\leq 5000$ & $994(40.03)$ & $190(19.11)$ & $804(80.89)$ & & \\
\hline $5001-10,000$ & $884(35.60)$ & $150(16.97)$ & $734(83.03)$ & & \\
\hline$>10,000$ & $605(24.37)$ & $106(17.52)$ & $499(82.48)$ & & \\
\hline \multicolumn{6}{|l|}{ Positive psychological responses } \\
\hline Being confident & & & & $80.584(1)$ & $<.001$ \\
\hline Yes & $2339(94.20)$ & $380(16.25)$ & $1959(83.75)$ & & \\
\hline No & $144(5.80)$ & $66(45.83)$ & $78(54.17)$ & & \\
\hline Being hopeful & & & & $47.537(1)$ & $<.001$ \\
\hline Yes & $2359(95.01)$ & $395(16.74)$ & $1964(83.26)$ & & \\
\hline No & $124(4.99)$ & $51(41.13)$ & $73(58.87)$ & & \\
\hline Being rational & & & & $113.526(1)$ & $<.001$ \\
\hline Yes & $2281(91.87)$ & $354(15.52)$ & $1927(84.48)$ & & \\
\hline No & $202(8.13)$ & $92(45.54)$ & $110(54.46)$ & & \\
\hline \multicolumn{6}{|l|}{ Information-seeking behaviors } \\
\hline \multicolumn{4}{|c|}{ Cannot stop searching information about the COVID-19 pandemic } & $37.118(1)$ & $<.001$ \\
\hline Yes & $1474(59.36)$ & $322(21.85)$ & $1152(78.15)$ & & \\
\hline No & $1009(40.64)$ & $124(12.29)$ & $885(87.71)$ & & \\
\hline \multicolumn{3}{|c|}{ Concerned about the COVID-19 pandemic } & & $37.195(1)$ & $<.001$ \\
\hline Yes & $1223(49.25)$ & $278(22.73)$ & $945(77.27)$ & & \\
\hline No & $1260(50.75)$ & $168(13.33)$ & $1092(86.67)$ & & \\
\hline \multicolumn{4}{|c|}{ Time spent consuming information about the COVID-19 pandemic (hours) } & $115.008(2)$ & $<.001$ \\
\hline
\end{tabular}




\begin{tabular}{cllll}
\hline Variable & Participants, $\mathrm{n}(\%)$ & Anxiety experienced, $\mathrm{n}(\%)$ & No anxiety experienced, $\mathrm{n}(\%)$ & Chi-square $(d f)$ \\
\hline$<1$ & $906(36.48)$ & $92(10.15)$ & $814(89.85)$ \\
$1-2$ & $1006(40.52)$ & $171(17.00)$ & $835(83.00)$ \\
$\geq 3$ & $571(23.00)$ & $183(32.05)$ & $388(67.95)$
\end{tabular}

Sources of information about the COVID-19 pandemic

Social media and commercial media

$\begin{array}{lll}\text { Yes } & 2159(86.95) & 408(18.90) \\ \text { No } & 324(13.05) & 38(11.73)\end{array}$

Central official media

$\begin{array}{lll}\text { Yes } & 2104(84.74) & 366(17.40) \\ \text { No } & 379(15.26) & 80(21.11)\end{array}$

Local official media, basic-level government and community

$\begin{array}{ll}\text { Yes } & 1508(60.73) \quad 262(17.37)\end{array}$

$9.826(1)$

.001

$1751(81.10)$

285 (87.96)

$3.004(1)$

.09

1738 (82.60)

299 (78.89)

$1246(82.63)$

$791(81.13)$

\section{${ }^{\mathrm{a}} 1 ¥=\mathrm{US} \$ 0.15$}

\section{Positive Psychological Responses}

The prevalence of anxiety according to the participants' positive psychological responses are presented in Table 1. We observed that the prevalence rate of anxiety was lower for the participants who felt confident $(2339 / 2483,94.20 \%)$, hopeful $(2358 / 2483$, $95.01 \%)$, or rational $(2281 / 2483,91.87 \%)$ about the COVID-19 pandemic $(P<.001)$.

\section{Information-Seeking Behaviors}

The distribution and prevalence of anxiety with different information-seeking behaviors during the COVID-19 pandemic is shown in Table 1. In this study, participants who could not stop searching for information about the COVID-19 pandemic $(1474 / 2483,59.34 \%)$ or those who were concerned about the pandemic $(1223 / 2483,49.24 \%)$ were found to have a significantly higher prevalence of anxiety $(P<.001)$ than other participants. The prevalence of anxiety was also observed to be higher for participants who spent more than 1 hour a day on searching for information about the COVID-19 pandemic $(P<.001)$.

Our study findings also showed that participants who sought information about COVID-19 via social media and commercial media $(2159 / 2483,86.95 \%)$ had a higher prevalence of anxiety $(408 / 2159,18.90 \%)$ than those who did not seek information through social and commercial media $(P=.001)$.

\section{Factors Associated With Anxiety}

Table 2 shows the final results of the multivariable logistic regression analysis. Participants who were confident (odds ratio [OR] $0.434,95 \%$ CI $0.243-0.775$ ) or rational (OR $0.286,95 \%$ CI 0.202-0.405) about the COVID-19 pandemic were found to be less likely to experience anxiety. In contrast, the information-seeking behaviors among the study participants, including cannot stop searching for information on COVID-19 (OR 1.593, 95\% CI 1.236-2.052) and being concerned about the COVID-19 pandemic (OR 1.389, 95\% CI 1.080-1.788) were found to be associated with anxiety. Moreover, participants spending more than 1 hour a day consuming information about the COVID-19 pandemic were also found to be more likely to report anxiety (1-2 h: OR 1.622, 95\% CI 1.209-2.176; $\geq 3$ h: OR $3.915,95 \%$ CI 2.823-5.430). Additionally, participants who chose social media and commercial media as the primary source of information about the COVID-19 pandemic were observed to be more likely to report anxiety (OR 1.531, 95\% CI 1.043-2.246).

Thus, the final model of multivariable logistic regression and forest plot (Figure 1) indicated that the following factors were associated with anxiety: cannot stop searching for information about the COVID-19 pandemic, being concerned about the COVID-19 pandemic, spending more than 1 hour a day consuming information about the COVID-19 pandemic, and use of social media and commercial media as the primary source of information about the COVID-19 pandemic. Conversely, being confident and being rational were independently found to be inversely associated with anxiety. 
Table 2. Multivariable logistic regression analysis for factors associated with anxiety.

\begin{tabular}{|c|c|c|}
\hline Variables & Odds ratio & $95 \% \mathrm{CI}$ \\
\hline \multicolumn{3}{|l|}{ Demographic characteristics } \\
\hline Gender (male vs female) & 1.135 & $0.898-1.435$ \\
\hline Age & 0.981 & $0.967-0.995$ \\
\hline Marital status (married vs other) & 0.927 & $0.648-1.327$ \\
\hline \multicolumn{3}{|l|}{ Occupation } \\
\hline Government worker, health care worker, teacher, lawyer, journalist (vs student) & 0.995 & $0.649-1.527$ \\
\hline Other (vs student) & 1.251 & $0.859-1.820$ \\
\hline \multicolumn{3}{|l|}{ Education } \\
\hline College and below (vs master's degree and above) & 1.177 & $0.810-1.711$ \\
\hline Bachelor's degree (vs master's degree and above) & 0.913 & $0.710-1.174$ \\
\hline \multicolumn{3}{|l|}{ Monthly income (¥) ${ }^{\mathbf{a}}$} \\
\hline$\leq 5000(\mathrm{vs}>10,000)$ & 1.253 & $0.925-1.699$ \\
\hline $5001-10,000(v s>10,000)$ & 1.061 & $0.788-1.427$ \\
\hline \multicolumn{3}{|l|}{ Positive psychological responses } \\
\hline Being confident (yes vs no) & 0.434 & $0.243-0.775$ \\
\hline Being hopeful (yes vs no) & 0.843 & $0.444-1.602$ \\
\hline Being rational (yes vs no) & 0.286 & $0.202-0.405$ \\
\hline \multicolumn{3}{|l|}{ Information-seeking behaviors } \\
\hline Cannot stop searching information on COVID-19 (yes vs no) & 1.593 & $1.236-2.052$ \\
\hline Concerned about the COVID-19 pandemic (yes. vs no) & 1.389 & $1.080-1.788$ \\
\hline \multicolumn{3}{|l|}{ Time spent consuming information of COVID-19 } \\
\hline $1-2 \mathrm{~h}(\mathrm{vs}<1 \mathrm{~h})$ & 1.622 & $1.209-2.176$ \\
\hline$\geq 3 \mathrm{~h}(\mathrm{vs}<1 \mathrm{~h})$ & 3.915 & 2.823-5.430 \\
\hline \multicolumn{3}{|l|}{ Sources of information about the COVID-19 pandemic } \\
\hline Social media and commercial media (yes vs no) & 1.531 & $1.043-2.246$ \\
\hline Central official media (yes vs no) & 0.836 & $0.611-1.143$ \\
\hline Local official media, basic-level government, and community (yes vs no) & 0.877 & $0.693-1.111$ \\
\hline
\end{tabular}

${ }^{\mathrm{a}} 1 ¥=\mathrm{US} \$ 0.15$ 
Figure 1. Forest plot of factors associated with anxiety.

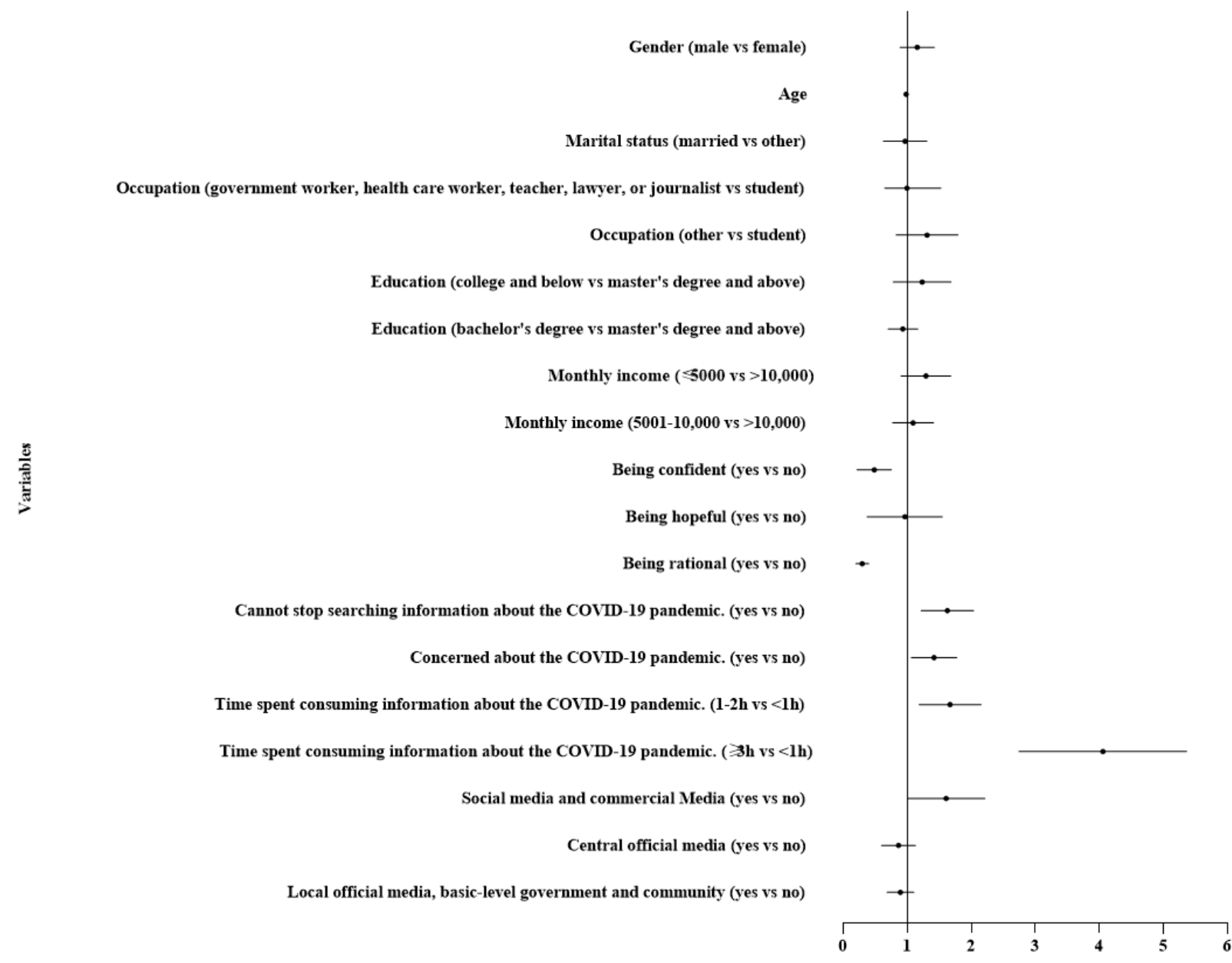

\section{Discussion}

\section{Principal Findings}

We observed that $17.96 \%$ of WeChat users in China who participated in this study reported having experienced anxiety during the early stages of the COVID-19 pandemic. This exceeds the prevalence of anxiety reported among the people in China before the pandemic $(3.2 \%-8.1 \%)[52,53]$. However, comparing the prevalence of anxiety during the severe acute respiratory syndrome (SARS) outbreak in 2002 (24.4\%-35.0\%), the prevalence of anxiety during the COVID-19 pandemic was slightly lower [54,55]. There remains a dearth of research on the relationship between information-seeking behaviors and anxiety during public health emergencies [56-58]. It is of vital importance to provide advice on how to cope with anxiety, including how to enhance positive psychological resources and prevent excessive information-seeking behaviors in order to prevent or reduce anxiety during public health emergencies. Our findings provide evidence-based recommendations on the promotion of positive psychological responses, psychological interventions, and information management to reduce anxiety for WeChat users in China.

Our study findings showed that anxiety was closely associated with positive psychological responses. Among the positive psychological responses, being confident and being rational were observed to be associated with lower prevalence of anxiety, which suggests that being confident and rational might prompt individuals to cope better with adverse events and difficult challenges during public health emergencies. Being rational also has been found to influence anxiety in previous studies, wherein people who were more positive coped better with life stressors and had low levels of anxiety $[59,60]$. WeChat users in this study had been exposed to a variety of stressors such as the perception of severe health risks of COVID-19, negative emotions associated with home quarantine, financial hardships caused by delays in work, and uncertainty during the pandemic, which might have resulted in reduced positive psychological responses and higher prevalence of anxiety. The framework of intolerance of uncertainty states that intolerance of uncertainty and cognitive avoidance are positively correlated with psychological responses and anxiety $[23,61,62]$.

People could cope with stressors better and improve their mental health by means of rational-emotive behavioral interventions and cognitive behavioral therapies to reduce anxiety and improve psychological abilities, including emotion regulation and stress management $[28,29,63,64]$. The emotion dysregulation model of anxiety suggests that the lack of emotion regulation has a positive correlation with anxiety $[65,66]$. Therefore, to intensify protective effects of positive psychological responses, psychological interventions for the 
public might be an effective approach, and these should be provided as soon as possible during public health emergencies.

This study also found that excessive consumption of information about COVID-19 might be closely linked with anxiety. Consuming information about the pandemic for more than 1 hour a day was observed to be associated with anxiety. Our results are consistent with other studies showing that anxiety is associated with increased use of smart phones, leading to excessive exposure to COVID-19 news [19,22,67,68]. The frequency and duration of searching for health information could exacerbate stress, anxiety, and perception of health risks [69-72]. WeChat users in this study might actively search or passively receive health information about the COVID-19 pandemic via multiple media sources. Searching for health information can be regarded as a source of anxiety and negative psychological responses. Spending too much time searching for health information could be linked to increased levels of anxiety, anger, or sadness. This might be due to increased fear of being infected by a severe disease and could adversely impact people's self-esteem and reduce their tolerance of uncertainty [73-81]. Conversely, it is also possible that anxious people are more likely to overconsume information. Health professionals should provide timely suggestions for the public on how to access and absorb health information from trusted sources $[77,82,83]$.

Moreover, sources of information about COVID-19 were found to be significantly associated with anxiety, especially information obtained via social media was observed to have a positive correlation with anxiety. Excessively searching for health information on social media during traumatic events (eg, public health emergencies, food safety incidents, terror attacks, and natural disasters) can result in sleep disorders, distress such as anxiety and depression, and posttraumatic stress disorder [84-89]. Social media provides open platforms for the public to exchange their ideas and perspectives in a timely and prompt manner. However, it might be difficult for the public to distinguish true information from false information. Through improved dissemination of health information, coping strategies and healthy behaviors in the context of the COVID-19 pandemic could be encouraged, in addition to focusing on the prevention of negative psychological responses and improvement on positive psychological responses [90].

\section{Limitations}

Several limitations should be acknowledged. First, the data were collected using a self-administered web-based questionnaire via smartphones, which may have resulted in information bias and misclassification bias. It is possible that participants did not provide accurate information in the study in order to either be included in the study or to move quickly through the survey. To minimize the bias as much as possible, a pilot study was conducted to acquire participants' perception of the questionnaire. Therefore, the collected questionnaire had been filtered with data cleaning, checking for consistency and logicality of the answers, adjusting invalid and missing values. Due to the severity of the COVID-19 pandemic and the necessity of timely acquisition of data, the survey was distributed via WeChat rather than conducted using a face-to-face approach. Additionally, this survey among WeChat users used a convenience sampling method during the first 2 months of the COVID-19 pandemic. Therefore, generalizability of the results may be limited to the whole population of China. As the survey was shared within academic WeChat groups, it is possible the results reported in our study are from a population that has a higher education level than the general population, and this may have affected anxiety levels either positively or negatively, because the participants likely had a stronger understanding of the pandemic. Future studies should be carried out with random sampling. Finally, the results may be limited by residual confounding from unmeasured confounders such as regional economic disparity, allocation of health resources, and an individual's social status. To minimize the potential errors induced by unmeasured confounders, the survey was conducted across 3 municipalities and 22 provinces via WeChat, one of the most popular social platforms in China.

\section{Conclusions}

The COVID-19 pandemic has adversely affected the mental health of the public and resulted in a high prevalence of anxiety among them, especially during the early stages of the pandemic. Certain behaviors such as cannot stop searching for information on COVID-19, being concerned about the COVID-19 pandemic, spending more than 1 hour a day consuming information about the COVID-19 pandemic, and using social media and commercial media as the primary source of information about the COVID-19 pandemic were found to be associated with anxiety. In contrast, positive psychological responses such as being confident and being rational were found to be negatively correlated with anxiety. Prompt measures and guidance from public health authorities on choosing reliable and trusted sources of information might decrease the negative effects of overconsumption of COVID-19-related information and improve the overall mental health of the public.

\section{Acknowledgments}

This survey was conducted using a web-based WeChat platform developed by the Department of Environmental Health, China Medical University, which was approved by the Public Behavior Research Project of Prevention and Control of COVID-19, China Medical University (grant number: 121-1210120025). The researchers also appreciate all of the study participants for their time to complete the survey.

\section{Authors' Contributions}

WZ and CZ were responsible for data analysis and drafting the manuscript. KS was responsible for the revision of the manuscript. FY, YJ, RM, and CC were responsible for the explanation of the data. XY was responsible for the study design. 


\section{Conflicts of Interest}

None declared.

\section{Multimedia Appendix 1}

The multivariable logistic regression analysis of anxiety (without positive psychological responses).

[DOC File, 42 KB-Multimedia Appendix 1]

\section{References}

1. Guan W, Ni Z, Hu Y, Liang W, Ou C, He J, China Medical Treatment Expert Group for Covid-19. Clinical characteristics of coronavirus disease 2019 in China. N Engl J Med 2020 Apr 30;382(18):1708-1720 [FREE Full text] [doi: 10.1056/NEJMoa2002032] [Medline: 32109013]

2. Archived: WHO Timeline - COVID-19. World Health Organization. URL: https://www.who.int/news-room/detail/ 27-04-2020-who-timeline---covid-19 [accessed 2021-04-29]

3. Coronavirus disease (COVID-19) Situation Report - 148. World Health Organization. URL: $\underline{\text { https://tinyurl.com/4pt69ybf }}$ [accessed 2021-04-29]

4. Real-time big data report of the epidemic [Data source: National Health Commission, People's Republic of China]. Webpage in Chinese. Baidu. URL: https://voice.baidu.com/act/newpneumonia/newpneumonia/?from=osari pc 3\#tab0 [accessed 2021-04-29]

5. Dong L, Bouey J. Public mental health crisis during COVID-19 pandemic, China. Emerg Infect Dis 2020 Jul;26(7):1616-1618 [FREE Full text] [doi: 10.3201/eid2607.200407] [Medline: 32202993]

6. Gao J, Zheng P, Jia Y, Chen H, Mao Y, Chen S, et al. Mental health problems and social media exposure during COVID-19 outbreak. PLoS One 2020 Jun;15(4):e0231924 [FREE Full text] [doi: 10.1371/journal.pone.0231924] [Medline: 32298385]

7. Yang Y, Peng F, Wang R, Yange M, Guan K, Jiang T, et al. The deadly coronaviruses: The 2003 SARS pandemic and the 2020 novel coronavirus epidemic in China. J Autoimmun 2020 May;109:102434 [FREE Full text] [doi:

10.1016/j.jaut.2020.102434] [Medline: 32143990]

8. Wang C, Pan R, Wan X, Tan Y, Xu L, Ho CS, et al. Immediate psychological responses and associated factors during the initial stage of the 2019 coronavirus disease (COVID-19) epidemic among the general population in China. Int J Environ Res Public Health 2020 Mar 06;17(5):1729 [FREE Full text] [doi: 10.3390/ijerph17051729] [Medline: 32155789]

9. Choi EPH, Hui BPH, Wan EYF. Depression and anxiety in Hong Kong during COVID-19. Int J Environ Res Public Health 2020 May 25;17(10):3740 [FREE Full text] [doi: 10.3390/ijerph17103740] [Medline: $\underline{32466251]}$

10. Gómez-Salgado J, Andrés-Villas M, Domínguez-Salas S, Díaz-Milanés D, Ruiz-Frutos C. Related health factors of psychological distress during the COVID-19 pandemic in Spain. Int J Environ Res Public Health 2020 Jun 02;17(11):3947 [FREE Full text] [doi: 10.3390/ijerph17113947] [Medline: $\underline{\text { 32498401] }}$

11. Huang Y, Zhao N. Generalized anxiety disorder, depressive symptoms and sleep quality during COVID-19 outbreak in China: a web-based cross-sectional survey. Psychiatry Res 2020 Jun;288:112954 [FREE Full text] [doi:

10.1016/j.psychres.2020.112954] [Medline: 32325383]

12. Lima CKT, Carvalho PMM, Lima IAAS, Nunes JVAO, Saraiva JS, de Souza RI, et al. The emotional impact of Coronavirus 2019-nCoV (new Coronavirus disease). Psychiatry Res 2020 May;287:112915 [FREE Full text] [doi: 10.1016/j.psychres.2020.112915] [Medline: 32199182]

13. González-Sanguino C, Ausín B, Castellanos MA, Saiz J, López-Gómez A, Ugidos C, et al. Mental health consequences during the initial stage of the 2020 Coronavirus pandemic (COVID-19) in Spain. Brain Behav Immun 2020 Jul;87:172-176 [FREE Full text] [doi: 10.1016/j.bbi.2020.05.040] [Medline: 32405150]

14. Asmundson GJG, Taylor S. How health anxiety influences responses to viral outbreaks like COVID-19: What all decision-makers, health authorities, and health care professionals need to know. J Anxiety Disord 2020 Apr;71:102211 [FREE Full text] [doi: 10.1016/j.janxdis.2020.102211] [Medline: 32179380]

15. Van Bortel T, Basnayake A, Wurie F, Jambai M, Koroma AS, Muana AT, et al. Psychosocial effects of an Ebola outbreak at individual, community and international levels. Bull World Health Organ 2016 Jan 21;94(3):210-214. [doi: $\underline{10.2471 / \text { blt.15.158543] }}$

16. Ozamiz-Etxebarria N, Dosil-Santamaria M, Picaza-Gorrochategui M, Idoiaga-Mondragon N. Stress, anxiety, and depression levels in the initial stage of the COVID-19 outbreak in a population sample in the northern Spain. Webpage in Spanish. Cad Saude Publica 2020;36(4):e00054020 [FREE Full text] [doi: 10.1590/0102-311X00054020] [Medline: $\underline{32374806]}$

17. Huang Y, Zhao N. Mental health burden for the public affected by the COVID-19 outbreak in China: Who will be the high-risk group? Psychol Health Med 2021 Jan;26(1):23-34. [doi: 10.1080/13548506.2020.1754438] [Medline: 32286091]

18. Kola L. Global mental health and COVID-19. Lancet Psychiatry 2020 Aug;7(8):655-657 [FREE Full text] [doi: 10.1016/S2215-0366(20)30235-2] [Medline: 32502468]

19. Nekliudov NA, Blyuss O, Cheung KY, Petrou L, Genuneit J, Sushentsev N, et al. Excessive media consumption about COVID-19 is associated with increased state anxiety: Outcomes of a large online survey in Russia. J Med Internet Res 2020 Sep 11;22(9):e20955 [FREE Full text] [doi: 10.2196/20955] [Medline: $\underline{\text { 32788143] }}$ 
20. Bao Y, Sun Y, Meng S, Shi J, Lu L. 2019-nCoV epidemic: address mental health care to empower society. Lancet 2020 Feb 22;395(10224):e37-e38 [FREE Full text] [doi: 10.1016/S0140-6736(20)30309-3] [Medline: 32043982]

21. Herrera S, Montorio I, Cabrera I. Effect of anxiety on memory for emotional information in older adults. Aging Ment Health 2017 Apr;21(4):362-368. [doi: 10.1080/13607863.2015.1093601] [Medline: 26460518]

22. Bendau A, Petzold MB, Pyrkosch L, Mascarell Maricic L, Betzler F, Rogoll J, et al. Associations between COVID-19 related media consumption and symptoms of anxiety, depression and COVID-19 related fear in the general population in Germany. Eur Arch Psychiatry Clin Neurosci 2021 Mar;271(2):283-291 [FREE Full text] [doi: 10.1007/s00406-020-01171-6] [Medline: 32691135]

23. Behar E, DiMarco ID, Hekler EB, Mohlman J, Staples AM. Current theoretical models of generalized anxiety disorder (GAD): conceptual review and treatment implications. J Anxiety Disord 2009 Dec;23(8):1011-1023. [doi: 10.1016/i.janxdis.2009.07.006] [Medline: 19700258]

24. Wells A. A cognitive model of generalized anxiety disorder. Behav Modif 1999 Oct;23(4):526-555. [doi: 10.1177/0145445599234002] [Medline: 10533439]

25. James A, Wells A. Religion and mental health: towards a cognitive-behavioural framework. Br J Health Psychol 2003 Sep;8(Pt 3):359-376. [doi: 10.1348/135910703322370905] [Medline: 14606978]

26. Görgen SM, Hiller W, Witthöft M. Health anxiety, cognitive coping, and emotion regulation: a latent variable approach. Int J Behav Med 2014 Apr;21(2):364-374. [doi: 10.1007/s12529-013-9297-y] [Medline: 23436185]

27. Mirhosseini S, Dadgari A, Basirinezhad MH, Mohammadpourhodki R, Ebrahimi H. The role of hope to alleviate anxiety in COVID-19 outbreak among community dwellers: An online cross-sectional survey. Ann Acad Med Singap 2020 Oct;49(10):723-730 [FREE Full text] [Medline: 33283835]

28. David D, Cotet C, Matu S, Mogoase C, Stefan S. 50 years of rational-emotive and cognitive-behavioral therapy: A systematic review and meta-analysis. J Clin Psychol 2018 Mar;74(3):304-318 [FREE Full text] [doi: 10.1002/jclp.22514] [Medline: $\underline{28898411]}$

29. Eseadi C. Rational-emotive behavioral intervention helped patients with cancer and their caregivers to manage psychological distress and anxiety symptoms. World J Clin Oncol 2019 Mar 24;10(2):62-66 [FREE Full text] [doi: 10.5306/wjco.v10.i2.62] [Medline: 30815372]

30. Leventhal H, Phillips LA, Burns E. The Common-Sense Model of Self-Regulation (CSM): a dynamic framework for understanding illness self-management. J Behav Med 2016 Dec;39(6):935-946. [doi: 10.1007/s10865-016-9782-2] [Medline: 27515801]

31. Schäfer JÖ, Naumann E, Holmes EA, Tuschen-Caffier B, Samson AC. Emotion regulation strategies in depressive and anxiety symptoms in youth: A meta-analytic review. J Youth Adolesc 2017 Feb;46(2):261-276. [doi: 10.1007/s10964-016-0585-0] [Medline: 27734198]

32. Gautreau CM, Sherry SB, Sherry DL, Birnie KA, Mackinnon SP, Stewart SH. Does catastrophizing of bodily sensations maintain health-related anxiety? A 14-day daily diary study with longitudinal follow-up. Behav Cogn Psychother 2015 Jul;43(4):502-512. [doi: 10.1017/S1352465814000150] [Medline: 24785012]

33. Hagger MS, Koch S, Chatzisarantis NLD, Orbell S. The common sense model of self-regulation: Meta-analysis and test of a process model. Psychol Bull 2017 Nov;143(11):1117-1154. [doi: 10.1037/bul0000118] [Medline: 28805401]

34. Grecucci A, Pappaianni E, Siugzdaite R, Theuninck A, Job R. Mindful emotion regulation: Exploring the neurocognitive mechanisms behind mindfulness. Biomed Res Int 2015;2015:670724 [FREE Full text] [doi: 10.1155/2015/670724] [Medline: 26137490]

35. Li H, Liu S, Yu X, Tang S, Tang C. Coronavirus disease 2019 (COVID-19): current status and future perspectives. Int J Antimicrob Agents 2020 May;55(5):105951 [FREE Full text] [doi: 10.1016/j.ijantimicag.2020.105951] [Medline: 32234466]

36. Li X, Xu S, Yu M, Wang K, Tao Y, Zhou Y, et al. Risk factors for severity and mortality in adult COVID-19 inpatients in Wuhan. J Allergy Clin Immunol 2020 Jul;146(1):110-118 [FREE Full text] [doi: 10.1016/j.jaci.2020.04.006] [Medline: $\underline{32294485]}$

37. Lin Q, Zhao S, Gao D, Lou Y, Yang S, Musa SS, et al. A conceptual model for the coronavirus disease 2019 (COVID-19) outbreak in Wuhan, China with individual reaction and governmental action. Int J Infect Dis 2020 Apr;93:211-216 [FREE Full text] [doi: 10.1016/j.ijid.2020.02.058] [Medline: 32145465]

38. Rodriguez-Morales AJ, Cardona-Ospina JA, Gutiérrez-Ocampo E, Villamizar-Peña R, Holguin-Rivera Y, Escalera-Antezana JP, Latin American Network of Coronavirus Disease 2019-COVID-19 Research (LANCOVID-19). Electronic address: https://www.lancovid.org. Clinical, laboratory and imaging features of COVID-19: A systematic review and meta-analysis. Travel Med Infect Dis 2020;34:101623 [FREE Full text] [doi: 10.1016/j.tmaid.2020.101623] [Medline: 32179124]

39. Shi Y, Wang G, Cai X, Deng J, Zheng L, Zhu H, et al. An overview of COVID-19. J Zhejiang Univ Sci B 2020 May;21(5):343-360 [ㅌREE Full text] [doi: 10.1631/jzus.B2000083] [Medline: $\underline{\text { 32425000] }}$

40. Singhal T. A review of Coronavirus Disease-2019 (COVID-19). Indian J Pediatr 2020 Apr;87(4):281-286 [FREE Full text] [doi: $10.1007 / \mathrm{s} 12098-020-03263-6]$ [Medline: $\underline{\text { 32166607] }}$

41. Sohrabi C, Alsafi Z, O'Neill N, Khan M, Kerwan A, Al-Jabir A, et al. World Health Organization declares global emergency: A review of the 2019 novel coronavirus (COVID-19). Int J Surg 2020 Apr;76:71-76 [FREE Full text] [doi:

10.1016/j.ijsu.2020.02.034] [Medline: $\underline{\text { 32112977] }}$ 
42. Wang J, Pan L, Tang S, Ji JS, Shi X. Mask use during COVID-19: A risk adjusted strategy. Environ Pollut 2020 Nov;266(Pt 1):115099 [FREE Full text] [doi: 10.1016/j.envpol.2020.115099] [Medline: $\underline{\text { 32623270] }}$

43. Wang Y, Wang Y, Chen Y, Qin Q. Unique epidemiological and clinical features of the emerging 2019 novel coronavirus pneumonia (COVID-19) implicate special control measures. J Med Virol 2020 Jun;92(6):568-576 [FREE Full text] [doi: 10.1002/jmv.25748] [Medline: 32134116 ]

44. Hu G, Rao K, Hu M, Sur Z. Preparing for and responding to public health emergencies in China: a focus group study. J Public Health Policy 2007 Jul;28(2):185-195. [doi: 10.1057/palgrave.jphp.3200130] [Medline: 17585319]

45. Zhang X, Wen D, Liang J, Lei J. How the public uses social media wechat to obtain health information in china: a survey study. BMC Med Inform Decis Mak 2017 Jul 05;17(Suppl 2):66 [FREE Full text] [doi: 10.1186/s12911-017-0470-0] [Medline: 28699549]

46. Kamangar F, Islami F. Sample size calculation for epidemiologic studies: principles and methods. Arch Iran Med 2013 May;16(5):295-300 [FREE Full text] [Medline: 23641744]

47. Liu Y, Guo N, Li T, Zhuang W, Jiang H. Prevalence and associated factors of postpartum anxiety and depression symptoms among women in Shanghai, China. J Affect Disord 2020 Sep 01;274:848-856. [doi: 10.1016/j.jad.2020.05.028] [Medline: $\underline{32664024]}$

48. Spitzer RL, Kroenke K, Williams JBW, Löwe B. A brief measure for assessing generalized anxiety disorder: the GAD-7. Arch Intern Med 2006 May 22;166(10):1092-1097. [doi: 10.1001/archinte.166.10.1092] [Medline: 16717171]

49. Plummer F, Manea L, Trepel D, McMillan D. Screening for anxiety disorders with the GAD-7 and GAD-2: a systematic review and diagnostic metaanalysis. Gen Hosp Psychiatry 2016;39:24-31. [doi: 10.1016/j.genhosppsych.2015.11.005] [Medline: 26719105]

50. Budikayanti A, Larasari A, Malik K, Syeban Z, Indrawati LA, Octaviana F. Screening of generalized anxiety disorder in patients with epilepsy: Using a valid and reliable Indonesian version of Generalized Anxiety Disorder-7 (GAD-7). Neurol Res Int 2019;2019:5902610 [FREE Full text] [doi: 10.1155/2019/5902610] [Medline: 31275648]

51. Zhong Q, Gelaye B, Zaslavsky AM, Fann JR, Rondon MB, Sánchez SE, et al. Diagnostic validity of the Generalized Anxiety Disorder - 7 (GAD-7) among pregnant women. PLoS One 2015;10(4):e0125096 [FREE Full text] [doi: 10.1371/journal.pone.0125096] [Medline: 25915929]

52. Hu Q, Wan Y, Su L, Li H, Jin Y, Li T. Prevalence of anxiety disorder among mainland residents in China: A meta-analysis. Article in Chinese. Chin J Psychiatry 2013;46(4):204-211. [doi: 10.3760/cma.j.issn.1006-7884.2013.04.004]

53. Tao J, Gong F, Lu J, Liang L, Liao X. Meta-analysis on the prevalence of depressive and /or anxiety disorder in general hospitals in China. Article in Chinese. Sichuan Mental Health 2018;31:73-78. [doi: 10.11886/j.issn.1007-3256.2018.01.018]

54. Fu C, Chen L, Lei L. Investigation and analysis of anxiety status of college students during the period of SARS. Article in Chinese. J of Health Psychol 2003;11(6):434-436. [doi: 10.13342/j.cnki.cjhp.2003.06.015]

55. Cheng SKW, Wong CW, Tsang J, Wong KC. Psychological distress and negative appraisals in survivors of severe acute respiratory syndrome (SARS). Psychol Med 2004 Oct;34(7):1187-1195. [doi: 10.1017/s0033291704002272] [Medline: 15697045]

56. Lai J, Ma S, Wang Y, Cai Z, Hu J, Wei N, et al. Factors associated with mental health outcomes among health care workers exposed to coronavirus disease 2019. JAMA Netw Open 2020 Mar 02;3(3):e203976 [FREE Full text] [doi: 10.1001/jamanetworkopen.2020.3976] [Medline: 32202646]

57. Que J, Shi L, Deng J, Liu J, Zhang L, Wu S, et al. Psychological impact of the COVID-19 pandemic on healthcare workers: a cross-sectional study in China. Gen Psychiatr 2020;33(3):e100259 [FREE Full text] [doi: 10.1136/gpsych-2020-100259] [Medline: $\underline{\text { 32596640] }}$

58. Wei N, Huang B, Lu S, Hu J, Zhou X, Hu C, et al. Efficacy of internet-based integrated intervention on depression and anxiety symptoms in patients with COVID-19. J Zhejiang Univ Sci B 2020 May;21(5):400-404 [FREE Full text] [doi: 10.1631/jzus.B2010013] [Medline: 32425006]

59. Carretta CM, Ridner SH, Dietrich MS. Hope, hopelessness, and anxiety: a pilot instrument comparison study. Arch Psychiatr Nurs 2014 Aug;28(4):230-234. [doi: 10.1016/j.apnu.2014.05.005] [Medline: 25017555]

60. Germann JN, Leonard D, Heath CL, Stewart SM, Leavey PJ. Hope as a predictor of anxiety and depressive symptoms following pediatric cancer diagnosis. J Pediatr Psychol 2018 Mar 01;43(2):152-161. [doi: 10.1093/jpepsy/jsx097] [Medline: 29049751]

61. Dugas MJ, Marchand A, Ladouceur R. Further validation of a cognitive-behavioral model of generalized anxiety disorder: diagnostic and symptom specificity. J Anxiety Disord 2005;19(3):329-343. [doi: 10.1016/j.janxdis.2004.02.002] [Medline: 15686860]

62. Dunsmoor JE, Paz R. Fear Generalization and Anxiety: Behavioral and Neural Mechanisms. Biol Psychiatry 2015 Sep 01;78(5):336-343. [doi: 10.1016/j.biopsych.2015.04.010] [Medline: 25981173]

63. Noormohamadi SM, Arefi M, Afshaini K, Kakabaraee K. The effect of rational-emotive behavior therapy on anxiety and resilience in students. Int J Adolesc Med Health Epub ahead of print posted online on June 8, 2019. [doi: 10.1515/ijamh-2019-0099] [Medline: $\underline{\text { 31188779] }}$ 
64. Sahranavard S, Esmaeili A, Dastjerdi R, Salehiniya H. The effectiveness of stress-management-based cognitive-behavioral treatments on anxiety sensitivity, positive and negative affect and hope. Biomedicine (Taipei) 2018 Dec;8(4):23 [FREE Full text] [doi: 10.1051/bmdcn/2018080423] [Medline: 30474604]

65. Kirwan M, Pickett SM, Jarrett NL. Emotion regulation as a moderator between anxiety symptoms and insomnia symptom severity. Psychiatry Res 2017 Aug;254:40-47. [doi: 10.1016/j.psychres.2017.04.028] [Medline: 28448803]

66. Suveg C, Morelen D, Brewer GA, Thomassin K. The Emotion Dysregulation Model of Anxiety: a preliminary path analytic examination. J Anxiety Disord 2010 Dec;24(8):924-930. [doi: 10.1016/j.janxdis.2010.06.018] [Medline: 20634040]

67. Huckins JF, daSilva AW, Wang W, Hedlund E, Rogers C, Nepal SK, et al. Mental health and behavior of college students during the early phases of the COVID-19 pandemic: Longitudinal smartphone and ecological momentary assessment study. J Med Internet Res 2020 Jun 17;22(6):e20185 [FREE Full text] [doi: 10.2196/20185] [Medline: 32519963]

68. Garfin DR, Silver RC, Holman EA. The novel coronavirus (COVID-2019) outbreak: Amplification of public health consequences by media exposure. Health Psychol 2020 May;39(5):355-357 [FREE Full text] [doi: 10.1037/hea0000875] [Medline: 32202824]

69. Muse K, McManus F, Leung C, Meghreblian B, Williams JMG. Cyberchondriasis: fact or fiction? A preliminary examination of the relationship between health anxiety and searching for health information on the Internet. J Anxiety Disord 2012 Jan;26(1):189-196. [doi: 10.1016/j.janxdis.2011.11.005] [Medline: 22137465]

70. McMullan RD, Berle D, Arnáez S, Starcevic V. The relationships between health anxiety, online health information seeking, and cyberchondria: Systematic review and meta-analysis. J Affect Disord 2019 Feb 15;245:270-278. [doi: 10.1016/j.jad.2018.11.037] [Medline: 30419526]

71. Sell TK, Watson C, Meyer D, Kronk M, Ravi S, Pechta LE, et al. Frequency of risk-related news media messages in 2016 coverage of Zika virus. Risk Anal 2018 Dec;38(12):2514-2524. [doi: 10.1111/risa.12961] [Medline: 29314118]

72. Elhai JD, Hall BJ, Erwin MC. Emotion regulation's relationships with depression, anxiety and stress due to imagined smartphone and social media loss. Psychiatry Res 2018 Mar;261:28-34. [doi: 10.1016/j.psychres.2017.12.045] [Medline: 29276991]

73. Ryan A, Wilson S. Internet healthcare: do self-diagnosis sites do more harm than good? Expert Opin Drug Saf 2008 May;7(3):227-229. [doi: 10.1517/14740338.7.3.227] [Medline: $\underline{18462181]}$

74. Stone J, Sharpe M. Internet resources for psychiatry and neuropsychiatry. J Neurol Neurosurg Psychiatry 2003 Jan;74(1):10-12 [FREE Full text] [doi: 10.1136/jnnp.74.1.10] [Medline: 12486258]

75. Gureje O, Ustün TB, Simon GE. The syndrome of hypochondriasis: a cross-national study in primary care. Psychol Med 1997 Sep;27(5):1001-1010. [doi: 10.1017/s0033291797005345] [Medline: $\underline{9300506}$ ]

76. Norr AM, Capron DW, Schmidt NB. Medical information seeking: impact on risk for anxiety psychopathology. J Behav Ther Exp Psychiatry 2014 Sep;45(3):402-407. [doi: 10.1016/j.jbtep.2014.04.003] [Medline: 24818986]

77. Sell TK, Boddie C, McGinty EE, Pollack K, Smith KC, Burke TA, et al. News media coverage of U.S. Ebola policies: Implications for communication during future infectious disease threats. Prev Med 2016 Dec;93:115-120. [doi: 10.1016/j.ypmed.2016.09.016] [Medline: 27664539]

78. Wormwood JB, Devlin M, Lin Y, Barrett LF, Quigley KS. When words hurt: Affective word use in daily news coverage impacts mental health. Front Psychol 2018;9:1333 [FREE Full text] [doi: 10.3389/fpsyg.2018.01333] [Medline: 30116210]

79. Myrick JG, Willoughby JF. Educated but anxious: How emotional states and education levels combine to influence online health information seeking. Health Informatics J 2019 Sep;25(3):649-660 [FREE Full text] [doi: 10.1177/1460458217719561] [Medline: 28728457]

80. Eastin MS, Guinsler NM. Worried and wired: effects of health anxiety on information-seeking and health care utilization behaviors. Cyberpsychol Behav 2006 Aug;9(4):494-498. [doi: 10.1089/cpb.2006.9.494] [Medline: 16901253]

81. Apaolaza V, Hartmann P, D'Souza C, Gilsanz A. Mindfulness, compulsive mobile social media use, and derived stress: The mediating roles of self-esteem and social anxiety. Cyberpsychol Behav Soc Netw 2019 Jun;22(6):388-396. [doi: 10.1089/cyber.2018.0681] [Medline: $\underline{\text { 31070455] }}$

82. Gardner B, Smith L, Mansfield L. How did the public respond to the 2015 expert consensus public health guidance statement on workplace sedentary behaviour? A qualitative analysis. BMC Public Health 2017 Feb 02;17(1):47 [FREE Full text] [doi: 10.1186/s12889-016-3974-0] [Medline: 28148236]

83. Caburnay CA, Kreuter MW, Luke DA, Logan RA, Jacobsen HA, Reddy VC, et al. The news on health behavior: coverage of diet, activity, and tobacco in local newspapers. Health Educ Behav 2003 Dec;30(6):709-722. [doi:

10.1177/1090198103255456] [Medline: 14655865]

84. Goodwin R, Lemola S, Ben-Ezra M. Media use and insomnia after terror attacks in France. J Psychiatr Res 2018 Mar;98:47-50. [doi: 10.1016/j.jpsychires.2017.12.006] [Medline: 29276963]

85. Leroy F, Brengman M, Ryckbosch W, Scholliers P. Meat in the post-truth era: Mass media discourses on health and disease in the attention economy. Appetite 2018 Jun 01;125:345-355. [doi: 10.1016/j.appet.2018.02.028] [Medline: 29486208]

86. Oh HJ, Lee $\mathrm{H}$. When do people verify and share health rumors on social media? The effects of message importance, health anxiety, and health literacy. J Health Commun 2019;24(11):837-847. [doi: 10.1080/10810730.2019.1677824] [Medline: $\underline{31609678]}$ 
87. Fukasawa M, Kawakami N, Nakayama C, Yasumura S. Relationship between use of media and radiation anxiety among the residents of Fukushima 5.5 years after the nuclear power plant accident. Disaster Med Public Health Prep 2021 Mar;15(1):42-49. [doi: 10.1017/dmp.2019.132] [Medline: 31779727]

88. Orui M, Nakayama C, Kuroda Y, Moriyama N, Iwasa H, Horiuchi T, et al. The association between utilization of media information and current health anxiety among the Fukushima Daiichi nuclear disaster evacuees. Int J Environ Res Public Health 2020 Jun 01;17(11):3921 [FREE Full text] [doi: 10.3390/ijerph17113921] [Medline: 32492886]

89. Pandey A, Patni N, Singh M, Sood A, Singh G. YouTube as a source of information on the H1N1 influenza pandemic. Am J Prev Med 2010 Mar;38(3):e1-e3. [doi: 10.1016/j.amepre.2009.11.007] [Medline: 20171526]

90. Basch CH, Hillyer GC, Erwin ZM, Mohlman J, Cosgrove A, Quinones N. News coverage of the COVID-19 pandemic: Missed opportunities to promote health sustaining behaviors. Infect Dis Health 2020 Aug;25(3):205-209 [FREE Full text] [doi: 10.1016/j.idh.2020.05.001] [Medline: 32426559]

\section{Abbreviations \\ GAD-7: Generalized Anxiety Disorder 7-item \\ KMO: Kaiser-Meyer-Olkin \\ OR: odds ratio \\ SARS: severe acute respiratory syndrome}

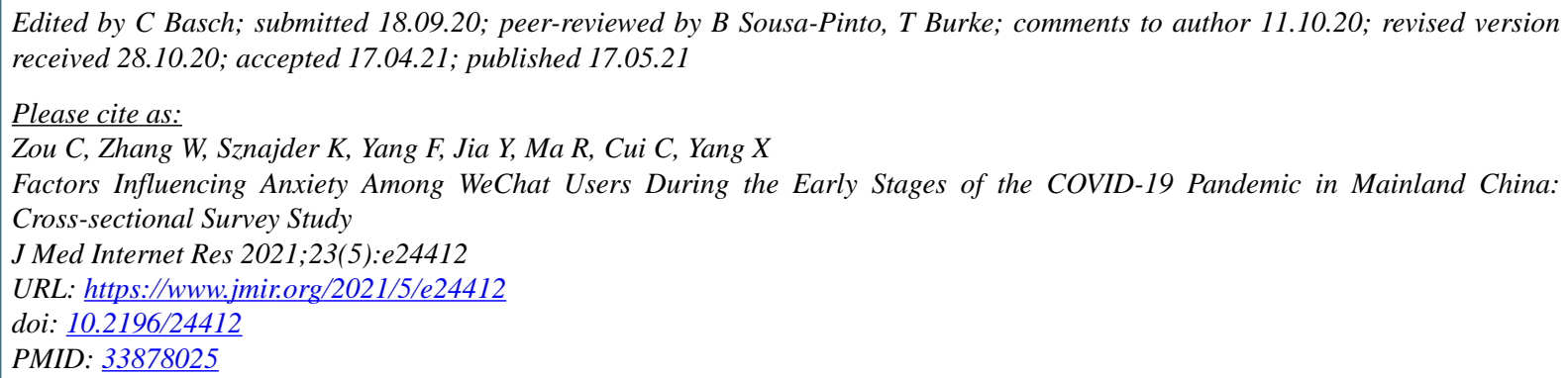

(C) Changqing Zou, Weiyu Zhang, Kristin Sznajder, Fengzhi Yang, Yajing Jia, Ruqing Ma, Can Cui, Xiaoshi Yang. Originally published in the Journal of Medical Internet Research (https://www.jmir.org), 17.05.2021. This is an open-access article distributed under the terms of the Creative Commons Attribution License (https://creativecommons.org/licenses/by/4.0/), which permits unrestricted use, distribution, and reproduction in any medium, provided the original work, first published in the Journal of Medical Internet Research, is properly cited. The complete bibliographic information, a link to the original publication on https://www.jmir.org/, as well as this copyright and license information must be included. 